\title{
University Campuses of Public Space and Subject of Architectural Design and Related Technical Infrastructure
}

\author{
Darja Kubečková $^{1, *}$, Šárka Kročová $^{2}$ \\ ${ }^{1}$ Faculty of Civil Engineering, VSB-Technical University of Ostrava, Czech Republic \\ ${ }^{2}$ Faculty of Safety Engineering, VSB-Technical University of Ostrava, Czech Republic
}

Received June 28, 2019; Revised August 27, 2019; Accepted September 4, 2019

Copyright $\bigcirc 2019$ by authors, all rights reserved. Authors agree that this article remains permanently open access under the terms of the Creative Commons Attribution License 4.0 International License

\begin{abstract}
The significance of public space is indispensable in every country. It is based on the traditional legal concept of public and thus general use. Essentially, it concerns spaces accessible to everyone irrespective of the ownership of this space. In contemporary Czech legislation, for instance, the concept of public space is not anchored. In practice, it is particularly used in an indirect form for some legal acts of municipalities aimed at limiting activities or drawing up charges for use. Public areas, public space, however, have indispensable significance for laying line structures of technical infrastructure determining the operational function of buildings and their sets. Besides classic public technical infrastructure, public space often also includes other elements of technical structures, such as internal water mains and sewers, natural gas and electric power distribution lines, etc. The public area issue can be demonstrated in a case study, which is the university campus of Technical University of Ostrava in the Czech Republic. The paper focuses on defining positive and negative aspects of public space used in this way for the public, its owner, and the potential of risks resulting from it. In the final part of the basic scope, the paper implies in which ways and by which means the risk can be mitigated. In order to find the optimal results of the analysis, it is always necessary to use a suitable method that identifies both the probability and the extent of adverse consequences resulting from the activity, equipment or system in question. For the technical infrastructure, answering the question, "what can go wrong? how likely is it? and what will be the consequences ?". Among other methods, the FMEA, FMECA method used in the risk analysis of this issue meets these requirements.
\end{abstract}

Keywords Public Space, Architectural Design, Technical Infrastructure, University Campuses

\section{Introduction}

At the present time, the significance and mission of universities is increasingly spreading in the awareness of the entire cultural and multicultural society strengthened. In the last decade, the concepts of the "third role of universities" and "university as a public space" have become modern, in which way the so-called "third role of universities" and the idea of the "university as a public space" are collocations employed by many universities throughout Europe as well as the entire world. The meaning or definition of the collocations of the "third role of universities" and "university as a public space" have not been given or specified unequivocally.

Whereas the concept of the "third role of universities" is construed as one rather related to the issue of the university and its practical cooperation, the concept of the "university as a public space" can rather be regarded as a part of public space in a certain form, contributing to the development of cities and habitations, not only in urban-conceptual terms, but also economic ones [1].

Theoretically, one can start from the word "campus", which is defined as the coherent premises of a university (college). The denotation "campus" is primarily used in the British or American environment; in recent decades, however, it has also been used in Central Europe relatively frequently.

A university campus involves buildings, lecture rooms, classrooms, libraries, laboratories, green areas, sports facilities and accommodation capacities - student hostels and other necessary technical infrastructure, frequently also links to scientific-technological parks or satellite research centres. All of this construction and technical infrastructure provides not only background for educational activities, but also background for creative scientific and innovative activities, cooperation with 
practice and state administration.

A typical campus covers an area of many hectares; as a rule, it is situated on the outskirts of cities and habitations. Its main advantage consists in the concentration of education, research, accommodation, sport and culture in a coherent, locally relevant campus. If various human activities are concentrated in a single chosen locality, it is possible to conclude that all of these activities are purposeful and lead to a certain fulfilment of an aim. This aim is to conceive a university and its environment as a place which primarily involves the activities of education, research and innovation, in which, nevertheless, activities are further developed in the context of the development of public space; ideologically, this can be characterized as a university and university campus as a place of studying, working, meeting, making friends, holding academic and social discussion, a place of university internationalisation. From this viewpoint, the university and the university environment as a whole is conceived as a place of mutual relations, a place of knowledge and a place of cooperation [2].

Nowadays, the collocation of words "university campus - third role - public space" is among the key subjects of professional discussion in various technical, social and sociologic disciplines. Therefore, it concerns broad multidisciplinary issues, mostly with a philosophical undertone. Undoubtedly, in urban, architectural, typological and structural terms, campuses complement public space in a substantial manner, determining the functional image of cities and habitations. If the mission of urban planning consists in the design and arrangement of habitations and their parts in synergy with architecture and design creation, the creation and development of university campuses and their urban areas is an integral part of this planning.

Within their further development, university campuses in Europe and the world place emphasis on strategies presenting the university environment as an educational and creative one, an internationalizing environment open to communication, an environment contributing to the improvement of the living environment, public space. The Massachusetts Institute of Technology (MIT), for instance, presents the university campus as "Designing a Campus for the Twenty-First Century", including the sustainability of buildings and technical infrastructure, all in relation to the continually developing campus.

Harvard University is introduced as a university in the global environment; the university's strategy leads to the protection of the environment; all activities of this university contribute to a reduction of the environmental load. Cornell University is presented in the same vein, while the university is also conceived as an institution contributing to the improvement of the living environment.

The University of Toronto brings its strategy even further, conceiving its vision and strategy as intelligent planning of the construction of the university focused on densification of the built-up area, paying attention to the surrounding countryside and assuming responsibility for high-quality architecture, structures and technical infrastructure on the campus, for natural and open spaces in the "green space and smart space" form. The functionality of the buildings and their utilization, reduction of the environment load, power supply and the environment of the structures are the priority together with the global dimension of the university.

Similarly, Delhi University of Technology places emphasis on planning in the territory, the protection of the environment, energies and power engineering.

The University of Amsterdam also solves areas within the university campus territory in relation to sustainable structures, energy-efficient buildings, sound buildings and sound environment. In the development and recovery of construction infrastructure, emphasis is placed on the change of utilization of the areas according to the university's needs, variability of buildings and variability of areas. The sustainable campus of this university reveres the idea of "Development and management of the built environment with due respect for people and environment".

Other strategies of universities and conceptions of university campuses are of a similar character (for instance, the University of Bath and Vrije Universiteit Brussel) [3].

Obviously, the universities' strategies, including further development of university campuses, are included in a number of major documents at both national and international levels.

\section{Materials and Methods}

The TUO strategic document, which is an integral part of the development of all universities in Europe [4], was used as the underlying research comparative material.

It has been hypothesized that urban, architectural and structural design of university campuses, including related infrastructure, is an appropriate element for creating public space [5]. Based on the theory of urban and urban creation, the urban development of university campuses is a conceptual and purposeful activity that contributes to the development of the city's settlements; in the urban concept with maximum measure eliminates risks (technical, infrastructure, territorial, etc.).

\subsection{Public Space and Its Significance for the Environment and Technical Infrastructure}

According to the statement of the Chamber of Deputies of the Parliament of the Czech Republic, the concept of public space occurs in 138 Czech legal regulations. In spite of the fact that the given concept is not exactly legally codified in the current legislation, it has indispensable significance; for instance in Act No. 128/2000 Coll. on 
Municipalities [6]. Its main purpose is to prohibit or regulate in the pertinent municipality by means of general binding regulations some activities which may violate public order, safety and functional values of the public area. Public space is also of particular importance for the application of Act No. 183/2006 Coll. on Town and Country Planning and Building Code [7], for the construction of object or line structures, such as those of technical and transport infrastructure:

- roads;

- natural gas distribution structures;

- $\quad$ electric power line structures;

- $\quad$ thermal energy distribution lines;

- $\quad$ water supply systems for public needs;

- $\quad$ sewerage systems for public needs.

The above-mentioned, as well as other constructions of technical and transport infrastructure, are not only constructions determining the further functionality of user objects, but they also substantially reduce the investment and operating costs which would have to be spent if public constructions of this type providing the operating functions were absent, for instance, in the case of the university campus of Technical University (hereinafter "TUO"). Their main purpose is to make these constructions accessible to the public, bring in the basic energies, drinking water and drain off wastewater from the places of its production for safe treatment of energies on a regional scale. For an illustrative example, the difference can be shown between a public utility construction of the technical infrastructure and an internal structure of distribution networks of line structures (Figure 1).

As is clear from the diagram in Figure 1, utilization of the public area for technical infrastructure constructions significantly reduces the length of the internal water main, determining the user function of the individual objects of construction sets. In the case illustrated, however, it does not only fulfil the technical-economical and purchase costs as well as the subsequent function, but it also has safety, fire and health significance. The water supply system of the water mains for public needs has a higher potential to satisfy hydraulic requirements for the supply of drinking and fire water to the individual supply points with constant quality and freshness of water [8]. Quality, freshness and wholesomeness of drinking water are among the most important conditions of its supply to the consumers $[9,10]$. Among others, they also enable reduction in the dimensions of the internal water main pipelines in as much as a substantial part of requirements for the supply of the fire quantity of water, for instance, to the outlet stands with a minimum capacity consumption of $35 \mathrm{l} / \mathrm{s}$ [11], is provided from the local water main, which is a significant multi-purpose source of fire water.

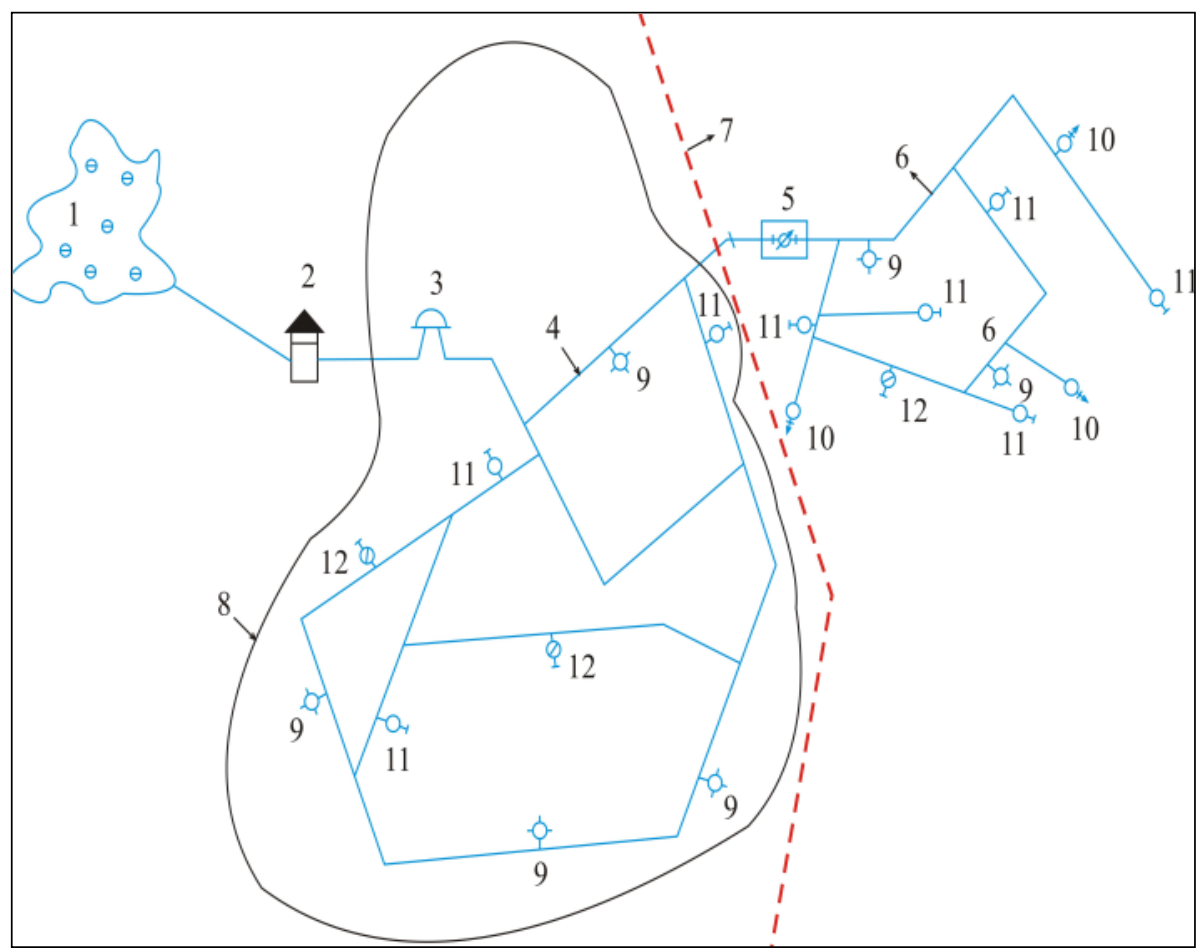

Figure 1. Water distribution diagram of water mains for public needs and internal water main (explanations: 1. source of drinking and fire water, 2. gas station, 3. accumulation of drinking and fire water, 4. water supply for public use, 5. water transfer point, 6. indoor water supply areal as example, 7. public water supply lines and internal water supply, 8. development of towns and villages, 9 . outlet device, 10 . hydrant as air tank, 11. hydrant of overhead, 12. underground hydrant) 


\subsection{Case Study - University Campus}

The case study shows the concept of urban development of public space, with a link to the university area. In the central part there is a campus area (1), a college dormitory (2), strategic planning addresses the area of the Innovation Center (3), nearby are quiet zones and areas for leisure activities, including sports activities (4). The line transport infrastructure connects the campus area with a residential area for living (5). The active role of public space is developed by an active "university-citizen" relationship, in the form of various activities and actions (Figure 2).

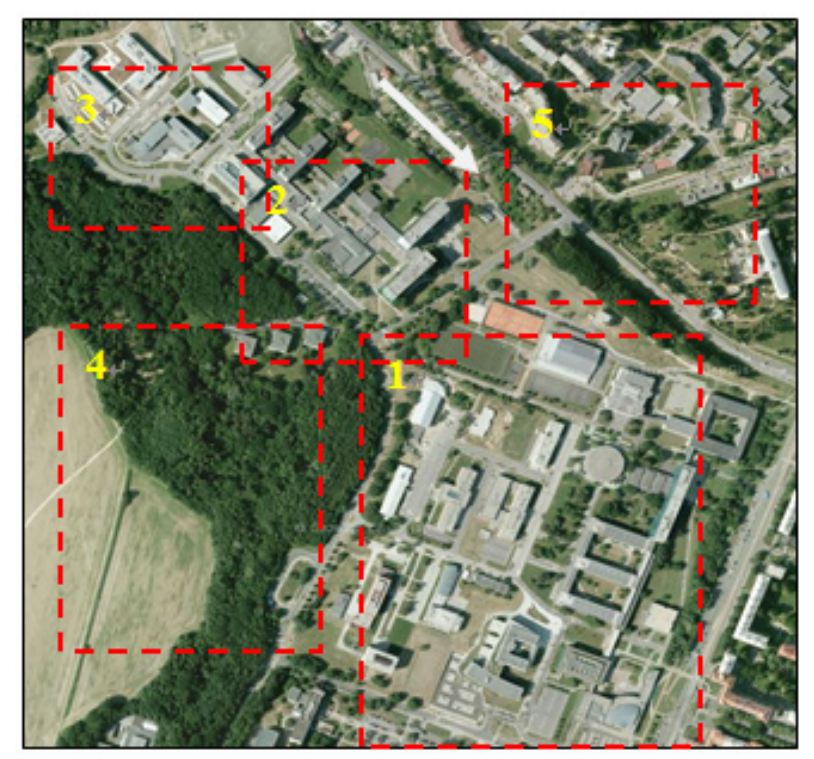

Figure 2. Urban area, part of Development plan [4]

\subsubsection{Positive and Negative Technical Properties of the} Public Area for the University Campus of TUO

With regard to the useful area, the university campus of TUO is mostly a public area. Its area of approx. 183,000 $\mathrm{m} 2$ indicates not only its significance for the city district called Ostrava-Poruba, but also the complexity of its maintenance and safety of its operation in different seasons. The given factors, negative and positive properties of the campus, must always be assessed and evaluated from several perspectives with regard to multi-purpose utilization of the entire system.

\subsubsection{Operational Safety Risks and Negative Properties of Public Spaces of the Campus}

As indicated in chapter 2.2.1 of this paper, operating a public area brings with it a wide range of safety risks and potential consequences of exceptional occurrences or accidents.

The major operational safety risks include the following events: occurrence of injuries to natural persons during use of the public area, liability for damages suffered by natural or juristic persons; increased alternative costs for maintenance of selected parts of the campus, insufficient awareness of the documentation on the technical infrastructure systems of foreign entities situated on the campus premises and costs of resolving exceptional occurrences in the given publicly accessible space.

In most cases, the above-mentioned, as well as other operational safety risks, can be eliminated sufficiently within preventive preparation for resolving exceptional occurrences [12]. One of the possibilities of approaching the given solution is illustrated (Figure 3).

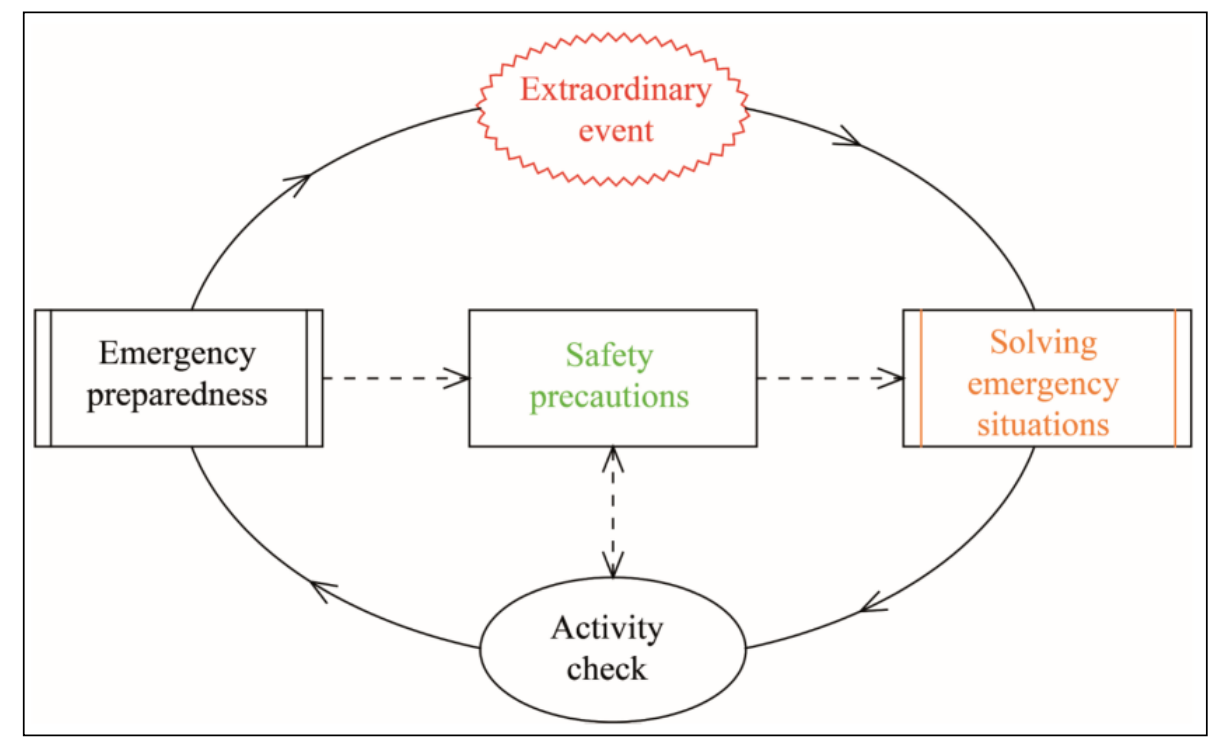

Figure 3. Concept of management of exceptional situations in the Czech Republic 
The indicated operational safety risks and subsequent safety measures for their elimination, however, need not be personally resolved by the owner of the property used for public purposes. A substantial proportion of the liabilities must be assumed by the locally relevant municipality; in the given case, the city district of Ostrava-Poruba. To mitigate potential disputes, however, it is suitable to settle this issue by means of an agreement between the given entities [13]. In spite of certain operational safety risks indicated, however, the strengths and positive factors prevail for the premises of the TUO campus.

\subsubsection{Strengths and Advantages of the Campus as a Public Area}

Within the assessment of the strengths and weaknesses in the operational safety risk analyses, the strengths of the system should prevail over the weaknesses [14]. Their prevalence consists not only in the immediate effect of the given arrangement, but particularly, in the wider context, it may manifest itself in the following aspects and areas:

(a) spatial possibilities of the campus development enabling the construction of new objects in the medium-term and long-term period of the technical university; (b) reduction in the actual purchase costs of construction of operational equipment of the technical infrastructure determining the function of campus object buildings;

(c) substantial reduction in the subsequent operating costs of maintaining the operational quality of internal water mains, sewerage systems and other technical equipment of power media on the campus premises [15];

(d) possibilities of architectural arrangement of the entire campus complex without the inevitable necessity of solving the space limits of construction units;

(e) increase in the university campus profile and its approximation to the public by means of the spaces open to the public;

(f) increased reliability of the given facility if suitable operating systems of the infrastructure are designed, including construction of devices for monitoring, for instance, the hydraulic efficiency of the internal water main (Figure 4);

(g) enhanced level of fire protection of objects by measuring the reliability and hydraulic parameters of the fire supply points, including monitoring of their behaviour at various service loads (Figure 5).

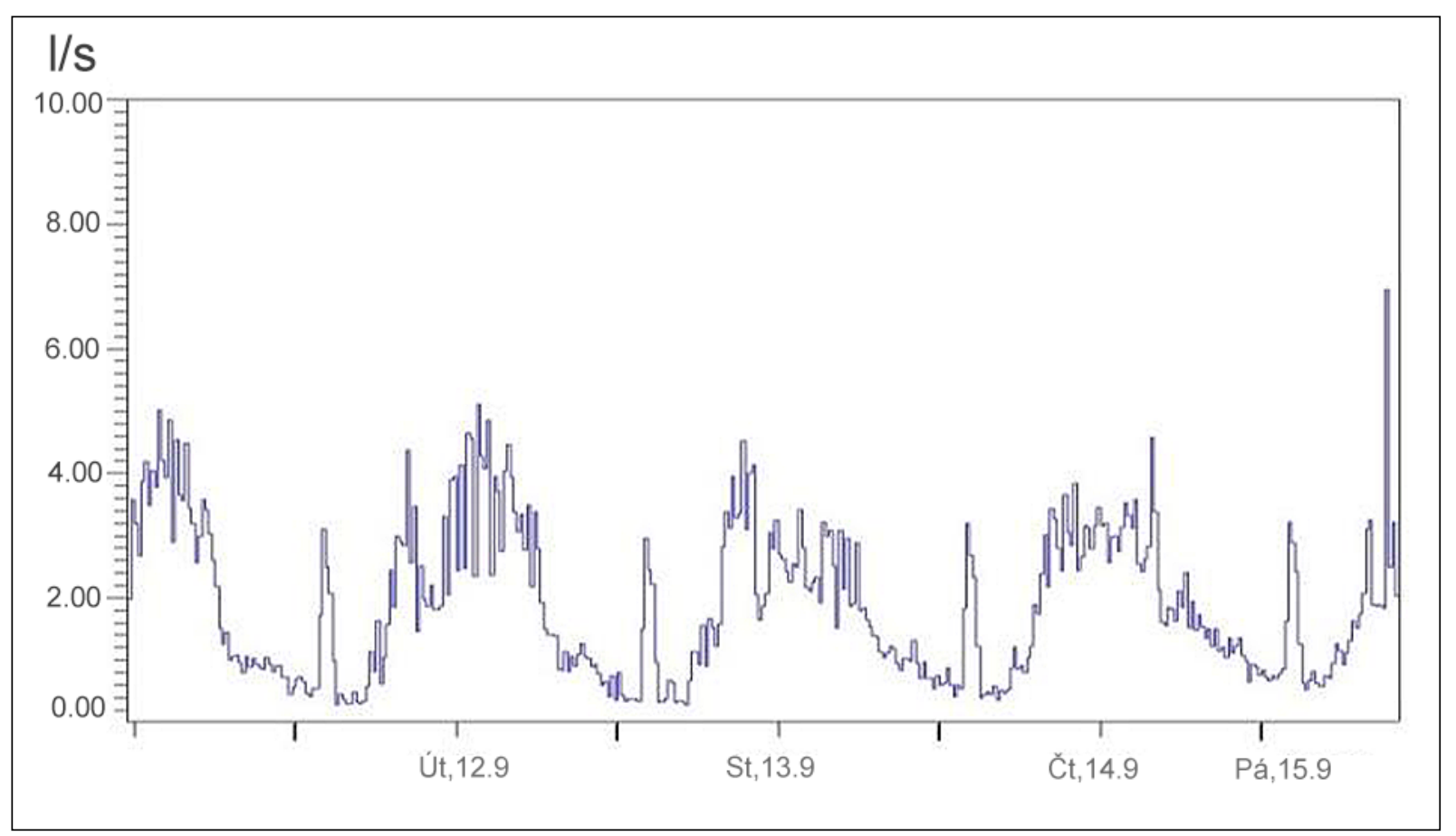

Figure 4. Example of the flow capacity of the main pipeline of the internal water mai 


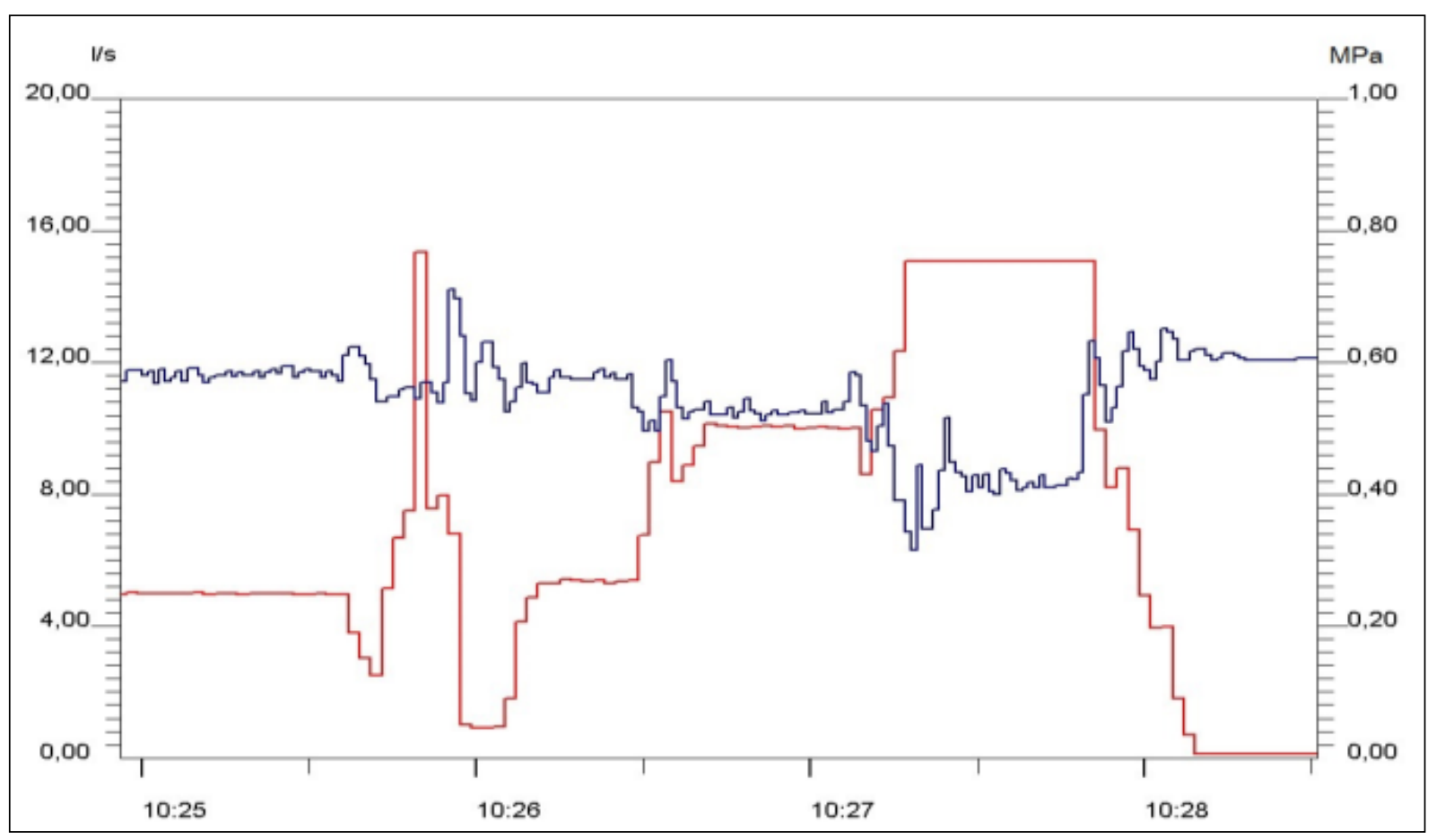

Figure 5. Graphic representation of hydraulic text of a supply point in the fire water supply (red line: flow of water $\left[1 . \mathrm{s}^{-1}\right]$ and dark blue lina: hydrodynamic pressure of water [MPa])

Knowledge of the hydraulic parameters of water supply systems and their behaviour in various operating and loading situations, see the illustrations above, enables the operator of the equipment to prepare sufficiently to resolve alternative exceptional events. The above-mentioned parameters of the load situations in the figures (Figure 4 and Figure 5) must be respected, in particular, for the supply points of the fire water from the discharge stands or capacity hydrants with increased requirements for the volume water supply.

The basic parameters of risk assessment reliability of technical infrastructure of water systems, clearly include a detailed knowledge of the quantitative values of water flow over time, from which it can be derived, among other things, the hydraulic efficiency of the system and its use in crisis situations (Figure 3). Since the internal water mains of the campus under consideration also serve as a multipurpose source of fire water for the university campus, it is necessary to know its behavior for the needs of fire water abstraction in crisis situations. Reliably, the required information can only be obtained by carrying out a hydraulic test of the fire water tapping point in question (Figure 4). This graph accurately documents the dependence of the capacity flow of water at the tapping point and its effect on the required hydrodynamic pressure ratios determined to ensure sampling point.

Achieving the hydraulic values shown in the graphs must be known and respected in general conditions for keeping the water system in working order. Basic conditions for their maintenance are given in the Table 1.
Table 1. Defining the conditions for keeping the water system in working order

\begin{tabular}{|l|l|}
\hline \multicolumn{1}{|c|}{ Term } & \multicolumn{1}{|c|}{ Definition } \\
\hline $\begin{array}{l}\text { Reliable supply of drinking and } \\
\text { fire water to campus facilities 24 } \\
\text { hours a day. }\end{array}$ & $\begin{array}{l}\text { Maintaining the specified } \\
\text { properties of the transported } \\
\text { medium for the functionality } \\
\text { of the campus sanitary and } \\
\text { fire systems. }\end{array}$ \\
\hline $\begin{array}{l}\text { Ensuring the quality and safety of } \\
\text { drinking water in a standard } \\
\text { environment even in the event of } \\
\text { emergencies at the source or } \\
\text { distribution system of drinking } \\
\text { water. }\end{array}$ & $\begin{array}{l}\text { Quantitative increase in } \\
\text { water flow in extreme } \\
\text { situations. }\end{array}$ \\
\hline $\begin{array}{l}\text { Maintaining the hydrodynamic } \\
\text { pressure of water in the pipe } \\
\text { system in parameters specified by } \\
\text { the legislation of the Czech } \\
\text { Republic and Czech Code for } \\
\text { water and fire systems. }\end{array}$ & $\begin{array}{l}\text { Hydrodynamic pressure of } \\
\text { water in the range of 0.25 to } \\
0.6 \text { MPa throughout the } \\
\text { distribution process. }\end{array}$ \\
\hline $\begin{array}{l}\text { Defining ways to ensure } \\
\text { emergency water supply (EWS) in } \\
\text { the event of emergencies in the } \\
\text { water system. }\end{array}$ & $\begin{array}{l}\text { Public } \\
\text { emergency plan and crisis } \\
\text { preparedness plan of the } \\
\text { campus operator. }\end{array}$ \\
\hline
\end{tabular}

Due to the fact that there are a number of emergency conditions caused by natural or anthropogenic influences at water facilities, the campus internal water supply system operator must also prepare instructions on how and how different types of events can be addressed. One of the options is given in Table 2, on the example of a worksheet for dealing with an emergency. 
Table 2. Example of a worksheet for dealing with an emergency on the internal water supply

\begin{tabular}{|c|c|c|c|c|}
\hline Term & Divergence & Possible & Aftermath & Activity required \\
\hline \multirow{4}{*}{$\begin{array}{l}\text { Supply of drinking } \\
\text { water for sanitary } \\
\text { needs of the campus } \\
\text { and drinking purposes } \\
\text { of water consumers. }\end{array}$} & \multirow{4}{*}{$\begin{array}{l}\text { Reduction of } \\
\text { hydrodynamic } \\
\text { pressure of water on } \\
\text { internal water. }\end{array}$} & $\begin{array}{l}\text { 1. Lack of raw water } \\
\text { in the water source. }\end{array}$ & $\begin{array}{l}\text { Decommissioning or substantial } \\
\text { reduction of the functionality of } \\
\text { the campus furnishing and } \\
\text { sanitary facilities. }\end{array}$ & $\begin{array}{l}\text { Provision of emergency } \\
\text { water supply (EWS) for } \\
\text { the whole area for the } \\
\text { duration of the accident } \\
\text { and interruption of water } \\
\text { supply. }\end{array}$ \\
\hline & & $\begin{array}{l}\text { 2. Public water supply } \\
\text { system accident. }\end{array}$ & As point 1 . & As point 1 . \\
\hline & & $\begin{array}{l}\text { 3. Accident on the } \\
\text { internal water supply } \\
\text { of the campus. }\end{array}$ & $\begin{array}{l}\text { As point } 1 \\
\text { to a limited extent. }\end{array}$ & $\begin{array}{l}\text { Restrictions on operation } \\
\text { and function in the part of } \\
\text { building structures, } \\
\text { depending on the } \\
\text { damaged part of the } \\
\text { internal water supply. }\end{array}$ \\
\hline & & $\begin{array}{lr}4 . \quad \text { An } & \text { alternate } \\
\text { automatic } & \text { pressure } \\
\text { station } & \text { (APS) } \\
\text { accident } & \text { or } \\
\text { interruption of power } \\
\text { supply to APS. }\end{array}$ & $\begin{array}{l}\text { Decrease of functionality or } \\
\text { decommissioning of equipment } \\
\text { dependent on increasing } \\
\text { hydrodynamic pressure of water } \\
\text { in campus area. }\end{array}$ & $\begin{array}{l}\text { Ensuring EWS for a part } \\
\text { of building structures } \\
\text { dependent on the APS } \\
\text { function. }\end{array}$ \\
\hline
\end{tabular}

Knowledge of the hydraulic conditions on the internal water supply and the procedures for emergencies amplifies the system's strengths and minimizes the risk of mismanagement of various situations.

Suitable integration of the strengths and their potential into the overall conception of the system solved on the basis of the analysis performed can substantially increase the reliability and overall efficiency of any subject equipment.

In the real environment, part of the construction units of object or line structures often happen to be implemented without a deeper initial analysis. Priority is given to seemingly simple projects; subsequently, however, they feature high operating costs and inadequate safety risks. The range of these alternative dangers can be reduced in various ways. One of them is an initial economic risk analysis within the concept of the overall assessment of potentials of utilization of the campus public space; for example in the Czech Republic using ČSN IEC 300-3-9 Reliability management - Risk analysis of technological systems, using the method "analysis of types of failure states and their consequences and analysis of types, consequences and criticality of failure states" (FMEA and FMECA).

These methods take sufficient account of the overall concept of risk and potential threat assessment for the technical infrastructure of the public open space and answer the project solver and the user of the project to the fundamental questions of the whole issue. Sample responses to critical and strategic questions are evident from sample graphs addressing the hydraulic efficiency issues of the local VSB campus water supply, their weaknesses and strengths in the operating modes of the system.

\subsubsection{Assessment of Practical Possibilities of Using Public} Space for the TUO Campus

Considering the usability of any piece of land, one should start from the general binding criteria based on law. Under the conditions of the Czech Republic, this legislative regulation is Act No. 183/2006 Coll. on Town and Country Planning and Building Code, as amended Act No. 12/2000. Among other terms for potential investors, the given law exactly defines the following areas in particular: built-up area, unbuilt area, unbuilt plot, area of supralocal or republic-wide significance.

The overall conceptual approach to the development of the TUO university campus must be based on these binding terms and factors. In particular, the indicated measures are binding tools of subsequent territorial planning. Within their framework, investors must particularly respect the aggregate analytic background materials indicated below, worked out for the administrative unit of the municipality with extended powers: land use study, territorial development policy, territorial development principles, and territorial plan.

By their correct practical application, optimum land use possibilities can be achieved, with simultaneous protection of the environment and its long-term sustainability. With the advent of climate changes, the protection of the natural environment has achieved a new dimension [16]. Protection of the natural environment must no longer be sectional only, but has to be conceived in a complex way on the basis of the risk analysis. The individual sectional steps in the territorial protection, particularly in the second half of the 20th century, have caused a wide variety of damage which can only be removed with difficulty.

Under the conditions of the Czech Republic, the most serious ecological damage is the changing conditions of 
rainfall water infiltration and drainage in the individual drainage areas of the state. Removal or at least mitigation of the occurring conditions is not only exceptionally expensive economically, but also technically difficult [17].

To achieve the maximum effect of minimization of secondary risks, the proposed solution must be preceded by a broad professional polemic and public discussion.

\section{Results and Discussion}

The purpose and aim of the study of the university campus as a place of public space and as the subject of architectural design of the Ostrava-Poruba city district was to assess the broader meaning of public space and its incorporation into possibilities and maximum utilization of technical infrastructure sustaining and optimizing the relationship between the capabilities and functional goals of these devices in the study. Due to the timelessness and long-term needs of the development of these specific areas, it is not possible to conclude the issue in question, even by an important act. The development of science and technology has a dynamic dimension and it is therefore appropriate to discuss the most appropriate way of further steps in the coming years.

An alternative discussion can be focused, for example, on the following topics:

a) new proposals for the ways and means to decrease the negative impact of unsuitable types of hydro engineering structures reducing the rain- and snowfall infiltration capacity of the territory;

b) proposal for new progressive monitoring processes resulting from climate changes for various types of technical infrastructure;

c) discussion on the new conception of elaborating methodologies to assess safety of the territory in the case of deficiency of surface and underground water for water supply, energy and technical purposes.

The results and conclusions arising from the professional polemic, however, must not remain merely formal acts of public discussion. State authorities and the local government of towns and municipalities should approach them with maximum open-mindedness, refusing only those proposals which are not practically feasible for scientific, economic or technical reasons.

The area of the TUO university campus has not only the potential to assess and fulfil the vast majority of complex ecological, legal and technical requirements, but also a sufficient number of scientific members, with knowledge of the risk analysis in various branches of human activity widely exceeding the regional or state borders.

Obviously, the text and structure of this paper shows the high need of the extent of public space not only for people, but also for the function of towns and municipalities. The given area, however, must not be merely a publicly accessible place, but a full-fledged purpose structure, fulfilling simultaneously its mission and ecological dimension. The university campus of TUO fulfils both of the indicated functions, thus having a prerequisite for being a significant and sustainable centre of life in the city district of Ostrava-Poruba. Nevertheless, the campus operators must continually keep pace with the dynamically changing conditions and predict potential reserves in the development plans, creating the conditions of their practical implementation. The method of approaching the given task is also indicated in its basic scope in the text of this paper.

\section{Conclusions}

Obviously, the text and structure of this paper shows the high need of the extent of public space not only for people, but also for the function of towns and municipalities. The given area, however, must not be merely a publicly accessible place, but a full-fledged purpose structure, fulfilling simultaneously its mission and ecological dimension. The university campus of TUO fulfils both of the indicated functions, thus having a prerequisite for being a significant and sustainable centre of life in the city district of Ostrava-Poruba. Nevertheless, the campus operators must continually keep pace with the dynamically changing conditions and predict potential reserves in the development plans, creating the conditions of their practical implementation. The method of approaching the given task is also indicated in its basic scope in the text of this paper.

\section{Acknowledgements}

The paper have been supported from the funds of Mnistry of Education, Youth and Sports of the Czech Republic, with support of the development projects in 2017 and Institutional support in 2019.

\section{REFERENCES}

[1] D. Kubečková. Third Role of Universities in Conditions of the 21 st century, UIIN Conference, $1^{\text {st }}$ to $3^{\text {rd }}$ June, 2016, Poster presentation, Amsterdam, 2016.

[2] J. Zelenková. Civil Buildings, School Buildings, CUT in Prague, Czech Republic, 2003.

[3] D. Kubečková. Third Role of Universities. Project IPn Credo, supported by the Ministry of Education, Youth and Sports, 2013-2015, CZ.

[4] Development Plan 2016-2020 (“general plan”). TUO, Ostrava, Czech Republic, 2016.

[5] D. Kubečková. The Structural Design of the Architectonics 
Details, $5^{\text {th }}$ Contemporary Design of the Architectonics Details, Saint Petersburg, Russia, 2015, invited speech.

[6] Act No. 128/2000 Coll. on Municipalities, as amended.

[7] Act No. 183/2006 Coll. on Town and Country Planning and Building Code (Building Act), as amended.

[8] Š. Kročová. Industrial Lanscape in the Period Drought, Journal of Inženiera Mineralna, Vol. 39. No. 1, 39-32, 2017.

[9] Regulation of the Ministry of Agriculture No. 428/2001 Coll. implementing Act No. 274/2001 Coll. on Public Water Supply and Sewerage System Collection of Lows 2004 (ch. 45).

[10] Act No. 258/2000 Coll. on Protection of Public health and on Amendment Town and Country Planning and Building Code (Building Act), as amended.

[11] Code 78 0873. Fire protection of Buildings-Equipment for Fire-Water Supply. Prague: Czech Standards Institute, 2003.

[12] J. Pokorný, H. Gondek. Comparasion of Theoretical Method of the Gas Flow in Corridors with Experimental Measurement in Real Scale, Journal of Acta Montanistica Slovaca, Vol. 21, No. 2, 146-153, 2016.

[13] V. Adamec, L. Maléřová, M. Adamec. How to Asses Territory Vulnerability. Conference Bohdaneč, Czech Republic, 35-34, 2016.

[14] Š. Kročová. Threats of Water Contamination in an Industrial Landscape, Journal of Inženieria Mineralna, Vol. 36, No. 2, 125-130, 2015.

[15] L. Gola, V. Václavík, L. Václavík, J. Valíček, M. Harničárová, M. Kušnerová, T. Dvorský. Drainage Concrete Based on Cement Composite and Industrial Waste. Advanced Structured Materials, 155-165, 2015 [cit. 2019-01-29].

[16] J. Daňhelka, M. Boháč and coll. Drought Evaluation in the Czech Republic in 2015 [online]. In: Prague: CHMU Prague, 2015, 2015-12, 160 [cit. 2015-12-23]. Available: h ttp://portal.chmi.cz/files/portal/docs/meteo/ok/SUCHO/zpr avy/Sucho_2015_CHMU_prosinec.pdf

[17] Š, Kročová, M. Bouchalová. Climate Changes and their Impact on the Surface Water Quality. Conference Water resources, forest, marine and ocean ecosystems, Sofia, Vol. 1, 161-167, 2016. 